\title{
OBSERVATIONS ON THE QUATERNARY GEOLOGY IN THE FISKENÆSSET AREA DURING THE SUMMER OF 1973
}

\author{
Anker Weidick
}

As part of the mapping of the Quaternary deposits for a map sheet in a scale of 1:500 000 (Frederikshåbs Isblink - Søndre Strømfjord) key areas were investigated in the coastal regions between Ravns Storø and Ameralik.

\section{Deposits and features related to the pleniglacial conditions}

Pleniglacial conditions were considered to be present during the time the coastal area was covered by the Inland Ice.

Observations of the altitudes of the bottoms of cirques indicate a general increase from $200 \pm 200 \mathrm{~m}$ at the outer coast to $900 \pm 200 \mathrm{~m}$ at the present margin of the Inland Ice. This coincides with an increase in the present glaciation limit from $700-800 \mathrm{~m}$ over the outer coast to $1000-1500 \mathrm{~m}$ at the margin of the Inland Ice. Since the cirque level is an approximate expression for the situation of the glaciation limit during the initial pleniglacial conditions, a lowering of the glaciation limit by $600 \mathrm{~m}$ can be deduced. This figure is in agreement with estimates on the depression of the glaciation limit in Arctic Eurasia during the glacial ages (Kaiser, 1969).

A general description of the glacial striae throughout the whole area has been given by Kornerup (1879) while Graff-Petersen (1952) has made a more thorough study of the southern part of the area. From these observations it is deduced that the Inland Ice once covered the entire region up to an altitude of $1300 \mathrm{~m}$ at Ameralik, and up to $600-250 \mathrm{~m}$ at Frederikshåbs Isblink close to the outer coast. The directions of the highest measured glacial striae indicate ice movement due west independent of the local topography.

The author investigated the younger systems of glacial striae from the various stages in the deglaciation of the area, especially those in the valleys connecting the fjords since here they indicate the overflow of ice from one fjord to another, thus furnishing a kind of relative age determination of the ice recession. From this it is concluded that the deglaciation of the southern part of the area started at the outer region of Fiskenæsfjorden and progressed from there to Frederikshåbs Isblink in the south and to Sermilik in the north.

\section{Deposits and features related to the Holocene recession of the Inland Ice margin}

Ice margin features occur scattered throughout the region (fig. 44) often connected to terraces indicating raised marine shore-lines. The marine limit decreased from more than $100 \mathrm{~m}$ above sea level at Ameralik in the north to $65-45 \mathrm{~m}$ at Frederikshåbs Isblink.

Shore-line diagrams furnish the means for a morphological correlation of the most frequent altitudes of raised beaches. The age of the shore-lines can be estimated from the 


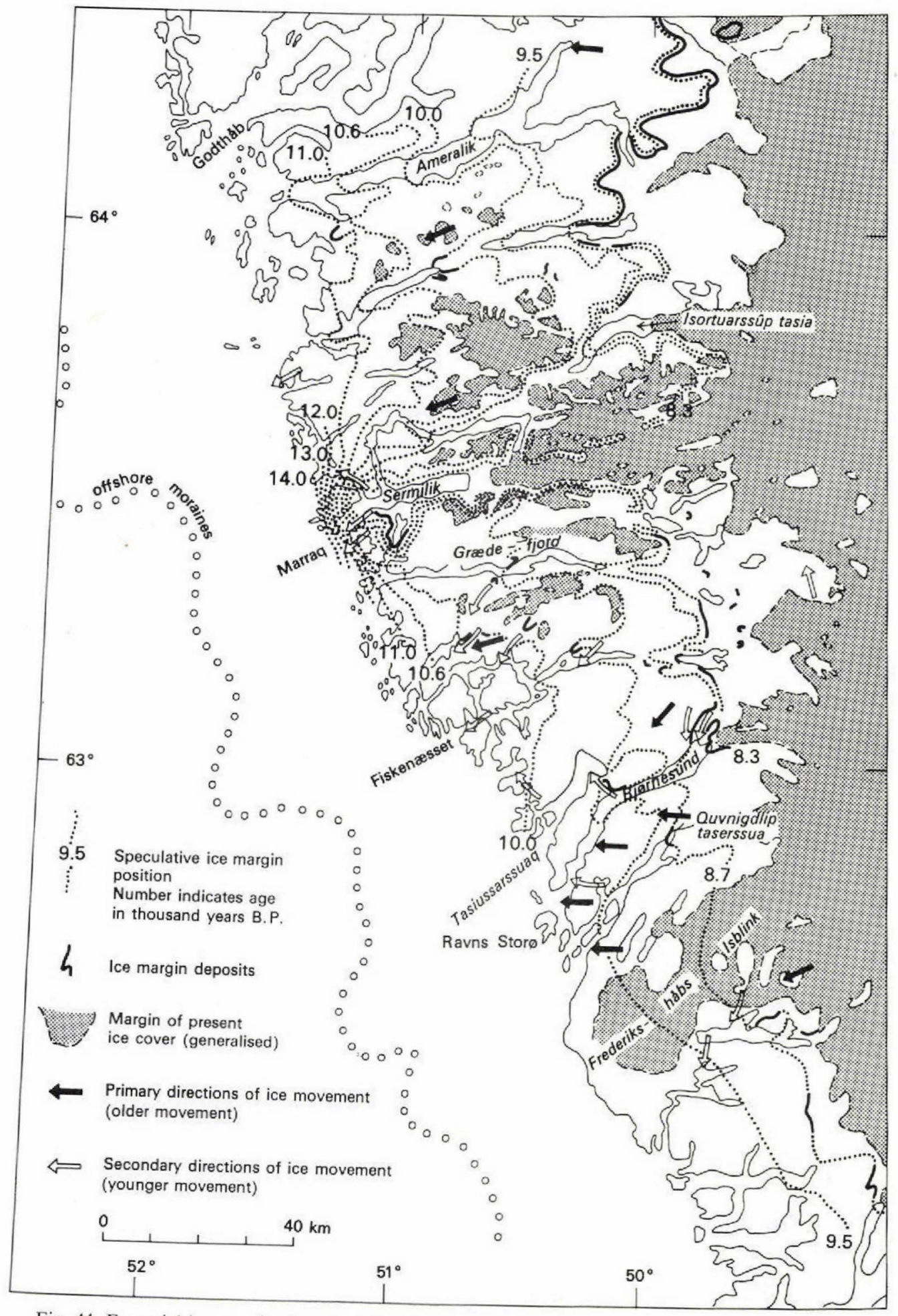

Fig. 44. Essential ice margin deposits (thick lines) and their correlation according to the age of the marine limit. Numbers indicate thousand years B. P. Black arrows: glacial striae on top of the mountains; open arrows: younger glacial striae in valleys. 
emergence curves drawn for Godthasbsfjord to the north of the region (Weidick, 1968, 1972b) and from just south of Frederikshåbs Isblink (Kelly, 1974). In the region itself dates from the Marraq plain are essential for correlation. The age of the marine limit is connected to the time of deglaciation which has the pattern shown in fig. 44 . This is also used for the correlation of the ice margin deposits.

The most pronounced belt of moraines occurs as a southern continuation of the Fjord stage moraines (Weidick, 1968) in Godthåbsfjord and at Marraq, and this very distinct zone of moraines can also be seen at the head of Bjørnesund. In Godthåbsfjord the age of the stage is estimated to be $8300-8100 \mathrm{~B}$. P. It is seen in fig. 44 that this morphological correlation fits into the age estimate of the deglaciation given by the marine limit. The early deglaciation around outer Fiskenæsfjorden given by the marine limit is also seen in fig. 44 from the direction of the younger glacial striae.

An early deglaciation of the area south of Frederikshåbs Isblink was postulated by Kelly \& Funder (1974) since they found undisturbed gyttja with an age of 9620 years B. P. close to the present margin of the Inland Ice in Kvanefjord. It is therefore concluded on the basis of the deglaciation pattern seen in fig. 44 that the margin of the Inland Ice during the Fjord stage both around Frederikshåbs Isblink and Kvanefjord might have had a position now covered by the present margin of the Inland Ice.

The trend of deglaciation is in accordance with information from other sectors of the Inland Ice (Weidick, 1972b). It is therefore suggested that in this region, as at other localities, the recession continued to somewhere around $6000-5000$ B. P. at which time the Inland Ice had a smaller extent than now. The concretions bearing marine shells present at the front of the Sermilik glacier and at the glacier lobe at the head of Godthåbsfjord (Weidick, 1972a) may therefore originate from hypsithermal marine deposits burried by the present glacier lobes.

\section{Late Holocene stabilisation of the Inland Ice}

The recession of the margin of the Inland Ice was interrupted 6000-5000 years ago by a readvance and subsequent minor fluctuations of the ice margin which is considered as a general stabilisation within the confines of the small climatic changes at this time. The sudden interruption of the recession appears to be best explained by an increase in accumulation over the Inland Ice since Atlantic time (Weidick, 1972a).

Since the recession continued beyond the Fjord stage and in the southern parts of the region appears to have continued behind the present extent of the Inland Ice it is possible that the formation of the Frederikshåbs Isblink glacier lobe is a result of a Late Holocene readvance burying the interstadial sediments. This stresses that the simple pattern of Early Holocene recession and Late Holocene stabilisation has to be modified by the changes in drainage of the margin of the Inland Ice due to change in ice thickness and subglacial topography.

Of the Late Holocene minor fluctuations only the recession of the last one is known. The advance was presumably initiated in the 17th century (Weidick, 1972a) and the recession might have started at the end of the last century though most occurred during this century. 


\section{References}

Graff-Petersen, P. 1952: Glacial morphology of the Quvnilik area. Meddr dansk geol. Foren. 12, 266274.

Kaiser, K. 1969: The climate of Europe during the Quaternary Ice Age. In Wright, H. E. (edit.) Quaternary geology and climate. Proc. 7th. Congr. int. Ass. Quat. Res. 16, 10-37.

Kelly, M. 1974: The marine limit in Julianehåb district, South Greenland, and its isostatic implications. In Blundell, J. D.: Crustal structure of the Gardar rift, South Greenland. Report on fieldwork 1973. Report from Department of Environmental Sciences, Univ. Lancaster, 17-26.

Kelly, M. \& Funder, S. 1974: The pollen stratigraphy of late Quaternary sediments of South-West Greenland. Rapp. Grønlands geol. Unders. 64, $26 \mathrm{pp}$.

Kornerup, A. 1879: Geologiske Iagttagelser fra Vestkysten af Grønland (62 $15^{\prime}-64^{\circ} 15^{\prime}$ N.B.). Meddr Grønland 1, 77-139.

Weidick, A. 1968: Observations on some Holocene glacier fluctuations in West Greenland. Bull. Grønlands geol. Unders. 73 (also Meddr Grønland 165,3) 202 pp.

Weidick, A. 1972a: Notes on Holocene glacial events in Greenland. Acta univ. Oulu., Ser. A, Scient. Rerum Natur. 3, Geol. 1, 177-204.

Weidick, A. 1972b: Holocene shore-lines and glacial stages in Greenland - an attempt at correlation. Rapp. Grønlands geol. Unders. 41, 39 pp. 